\title{
W.J. Leonhardt
}

DE89 014712

AGS Depurtment, Brookhaven Natlonal Labocatocy

\section{Abetrect}

A C-cype sepeum dipole magnet is located $600 \mathrm{~mm}$ downerrese of che priasy terget in an external bean itne of the ACS. Conventional use of flber gland epoxy electrical insulation for the magnet colls results in their fallure after a relatively short running period, therefore a radiacion hard insulation system is required. This is eccomplished by replacing the existing copier conductor with a copper conductor having a this aluminum skin which is anodized to provide the electrical insulation. since the copper supports a current density of $59 \mathrm{~A} / \mathrm{am}^{2}$. no reduction in cross sectional area can be colerated. Deaign conelderactons, manufacturing cuchniques, and operating experience of a protocype dipole la presenced.

\section{Introduction}

Equipwent located near the flxad target sta1ong 1r. the ACS Experiaental Areas is subjected co high levela of radiation and thue prone to danage after ahort running time. One target sation in particular hat the colls of a c-type aeptun dipole megnet (10C20) located fuse 600 wh away frov the production target itself. Currently, these colls are subjected to a radiation dose of betwaen $10^{9}$ and $10^{10}$ rads/(15 week cunning parlod) and this dosage 1s expected to Increase five fold when the AGS Booster comes on-line.[1] Since the radiacion realstance of good organic insulators is less than $10^{9}$ rads, a new coll deslgn was required which provided for electrical insulation to be made from Inorganic materials. The operating parameters of the exiscing magnet are given in Table?.

\section{Table I}

Operating Parawetere of 10C20 Magnet

\begin{tabular}{|c|c|c|}
\hline $\begin{array}{l}\text { Meximum Fleld } \\
\text { Voltage } \\
\text { Current } \\
\text { Mean Effect1ve Length } \\
\text { Water Flow } \\
\text { Gap } \\
\text { Rectangular Conductor }\end{array}$ & $\begin{array}{c}1.2 \\
44 \\
3300 \\
500 \\
57 \\
57 \\
9.4 \\
\$ 5.05\end{array}$ & $\begin{array}{l}T \\
V \\
A \\
\lim \\
\min (\mathrm{in} \\
\min x 8.15 \mathrm{~mm} x \\
\min \end{array}$ \\
\hline
\end{tabular}

In addicion to providing a "radiation hard" Inoulation oysten, the new coll for the $10 \mathrm{C} 20$ magnet needed to be approximately the ane alze as the ex1sting colls. Equipnent is packed-in rather tightly around this agnet and any significant dimensional changes to this coll would inpact adjolning equipmene. This essentally ruled out the use of magneslum-oxide or mineral insulated (MI) conductor - Ince lta poor pecking factor (32 to 46\%) would require the coll to grow agnificantly to provide the orlelnal number of amp-turna..(2)

Seversl year ago, Coluable Universtey' Nevls Leburaturtes facud a Intiar nuod for radintion liurd

*Work performed under the ausplces of the U.S napurtunnt of silarxy. colls and developed colls wound from aluminum conductors whose surface wal hard anodized to provide electrical insulation. [3] Th1s proved to be a succeseful epproech and, following their ues at vevis, four quadrupoles of this design were brought to Brookhaven and have run without problems in the AGS Experimental Areal for over three years. Alualnun conductors were considered for the replacenent colls, however, they were judged to be unsultable ince they could not support the $59 \mathrm{~A} / \mathrm{mm}^{2}$ current density exlecting in the present colla. Addictonally, no metallurgical process could be found which would alter the wurface of copper conductors wuch a anodizing does for aluminu conductors to provide the needed electrtal insulation.

\section{Alcled Approach}

Stnce coppoe could handlo tho raqulrad currunt denelty and luminum could have tis aurface ade electrically non-conducting, a procese wae needed which would conblne the two nateriala. The wot natural epproech was to uae the exlating copper croes-aectional dimenatone and add aluminus to the outer surface of the conductor in the space traditionally allocated to flber glane tape and epoxy resin. Since, in all probablifty, the aluminum chlcknese would be less than the epoxy-fiber glaes, - ilghtly sualler coll could be bulle with the original performance capabilities.

Finding a process Eor applying on aluninua surface to copper proved to be a very difficult task. Aluminum will not adhere to copper in a dippling process and while copper can be plated ontn aluninum, the opposite is not crue. Vecuun deposition or uputearing way judyed to be too labor Intenatve or juat generally impractical. cladding operationa were then considered. Aluminua cled cable is uaed in the Cable T.V. bualneas and the cable it ade by sandwiching a cound copper conductor between two thin sheere of aluminum and then paseing it all through aet of rollera which have a circular groove in thatr arface. The aluminua is bonded to the copper by the extrene pranaure frol tha roll. and excese aluminum is slit off. No vendor, however, could be found who would attempt to clad square or rectangular magnet conductor in this fashion.

Finally a procese for cladding the copper conductors wae identifled. Copper conductors were fabrlcated usling a conventional drawing procesa to produce the copper in lts final rectangular craes sactIon with a circular hole inaide. When all the copper drawing was completed, 1t was fully annealed. A thin wall circuler eluntnum tube wa then drawn whose Inalde dianerer would allow the ractangular copper to be ineerted Into 1t. Alloy 1100 was chosen for the aluminum afnce it is a good candidate for anodizing. Next the copper was Inserted the full length in the lualnum tube and the two ware drawn elirough a rectangular die whtch was izad to provide - 0.25 in aluminum ukin uvar the copper. The aluninum-copper assenbly was then heated to anneal the aluminum. The copper remained in the annealed 
condition througho:st the aluninum drawing process.

In ninimize any work hardenting of the innturlul, It was produced, shipped, and brought to the winding procoun (1) Etrn!ght longthe of 10 metery. Thlm lis cufficient co provido one somploce witer puch for the present ragnet requireaents. Longer lengths can be produced, however the macartal whild have in be

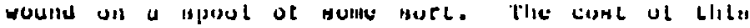
acterlul was approximacely $\$ 30$ US/ weter.

\section{Souc Musnel}

Once it was shown that alumbnum clad conductors could be produced, it wae decided to conetruct a anall teet aegnet to gain experlence with winding ch1s new atcerial inco colls, enodizing theec colle, and then running the colle at the same currenc and fleld as in the full alze agnet. A croes sectional vlew of chla agnet is hown in F1E. l. "Racecrack" cype colls were uaed racher than the octual "aaddle-eype" colle uned in the 10C20 magnat since they were cnelar to wind.

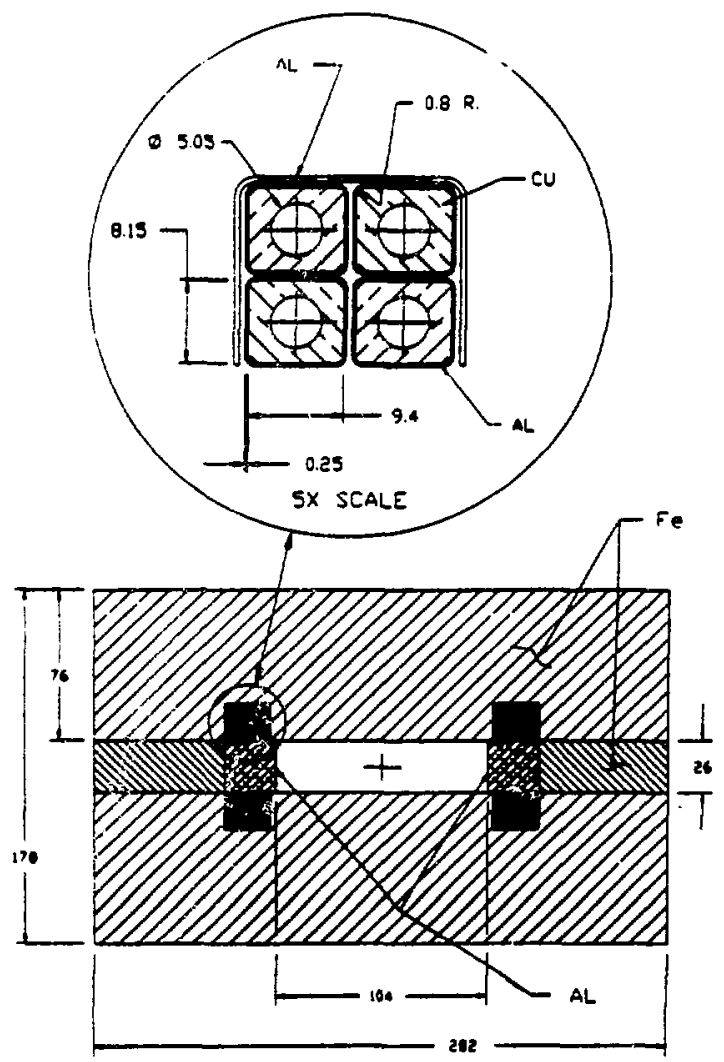

Pig. I Alclad Teat Magnet (Cort $356 \mathrm{~mm}$ long)

Since the nnodized conting la brltele in nacure. Che colln wero fully tormed minl then nuodtzod. The anodizing process was slallar to that used for the Nevis colla. The steps are sollow:

1. Iland poliuh with "Scutch Brite".

2. Soap cleaner.

3. Watce elinus.

4. Lecli Hich Sodian Ilydruxida, $37 \mathrm{~g} / \mathrm{t}$, at $49^{\circ} \mathrm{C}$ for one ninute.

i. Hater rinan.

6. Deuxldize in Nicilc Acid and ferrous Chloride at $43^{\circ} \mathrm{C}$ for two alnutes.

7. Rinse geveral times with water.

8. Hard coac milodize in $20 \%$ Sulfuric Acid, $200 \mathrm{~g} / \mathrm{l}$ at $2^{\circ} \mathrm{C}$ and $388 \mathrm{~A} / \mathrm{m}^{2}$ uaing a $316 \mathrm{~L}$ -tainlens teel tank at the cnthode.

9. Wacer rinse.

10. Nickel seel for 5 al nutee in $0.5 \pi$ eolution of Nickel Acetate at close to bolling.

Th1e procese provided an enodized coating epproximately 0.07 to 0.08 an thick and cost approximetely $\$ 300$ US for the two teat colly.

Ono of the nnorlized taet colle it whown in E1g. 2. The anodizing leavee the colle with a very lark tray color. Slnce any expoued copper on the colle would ruin the enodizing canke, the enodizins vendor masks any area which copper shows or aey ahow

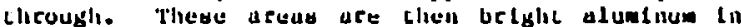
color and easy to see. Each tent coll had several of these areas as shown in Elgures 2 and 3 . Firure

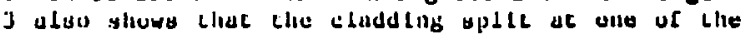
bends.

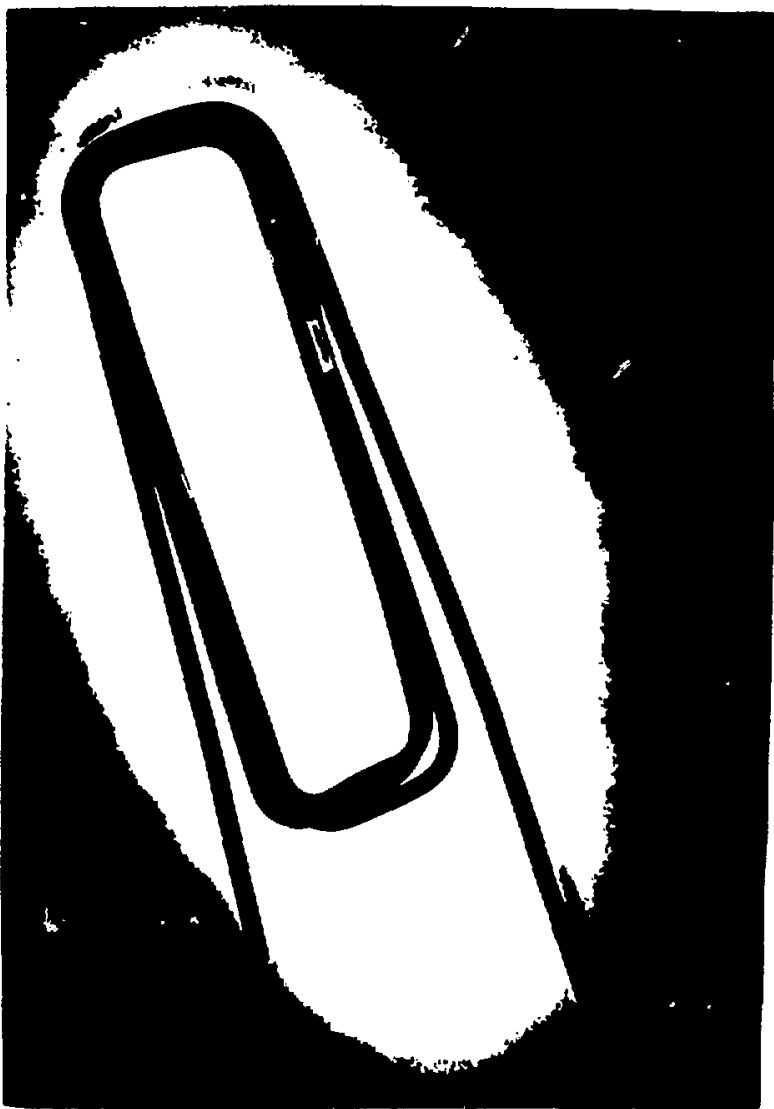

Fig. 2 Anodized coll. Sright areas have on Iaperfection and linva not boen anodlead. 


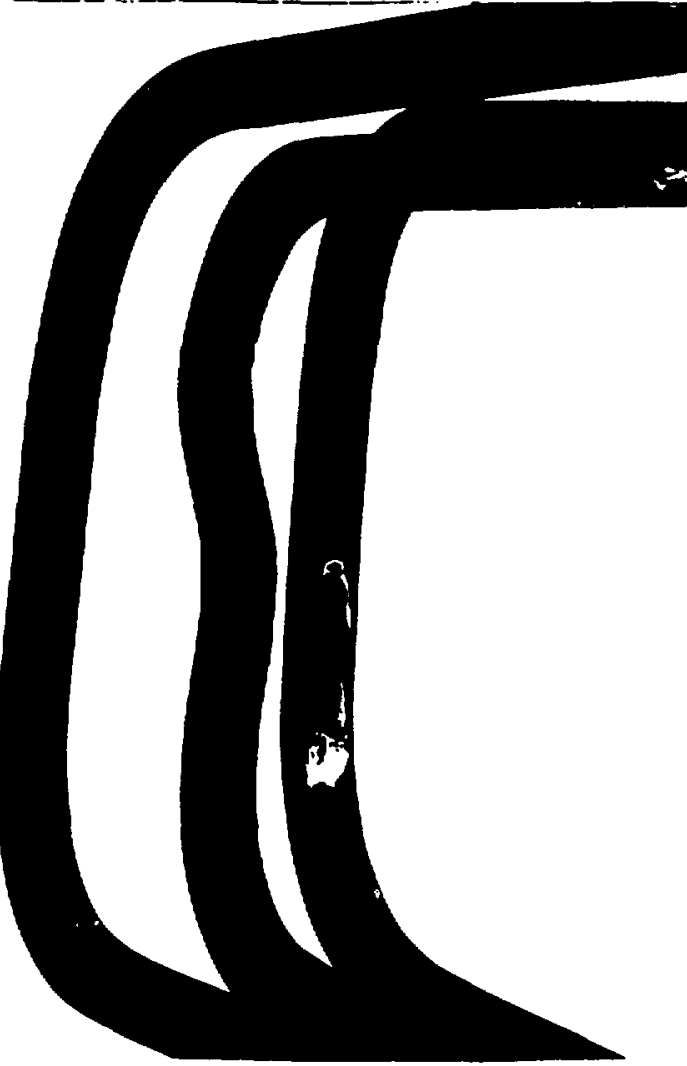

Flg. 3 Anodlzed coll showlng opltt and uninmulnted areas.

\section{Teet Regults}

It was decided that ince none of the unanodlzed arase linud up wich any ocher unanadizad erea, testing could proceed and thlo would be "woret caue" teac. The colle were tightly bound with cable ttes and each impulee teated (ring teat) to $600 \mathrm{v}$ wth no curn-to-turn thorte detected. Next the colls were inserted into the teot core as own in F1g. 4. Each cotl was eurroundad by an anodized aluminum channel and tested with 500 Vdc to ground with no breakdowns. Breakdown did occur at $1000 \mathrm{Vdc}$ but since the $10 \mathrm{C} 20$ only sune at $44 \mathrm{Vdc}$, It was fudged that pasoing the 500 Vdc test was sufficient.

The agnet was then powered up and the full 3300 A paued through the coll. To provide the full operating current, a $450 \mathrm{~kW}$ power supply was used whlch gave a paeudo DC output of $10 \mathrm{~V}$ rat at $360 \mathrm{~Hz}$. Th1. power oupply ripple cauces the colle to vibrate in operation, and while thle vibration was not a probles during the short-cera ceeting, it is noc known whethar it wl11 adversely etfect the anodized ineulation after a lons running period. Water flow ratee were adfueted to weth the $10 \mathrm{C} 20$ megnet and the col1s ran without e problew at $79^{\circ} \mathrm{C}$. Long term teeting reweine to be done.

\section{Sunenery}

A procese for cladding conventional coppor magliet conductor with eluminum lias hoon duvolupod and, after toralns the conductors lnto colls, the
Luminum hau been hard anodlzed to provide a radiacion tedetant electrical ineulation. Short tera testing on a snall dipole agente hes shown thot these colls meet performance requirenente. Long turie testing te requited to seudse the offectu of powar upply inducud vibration and corronton in en electromagnetic radiation environsent. Besed on the oncourasing rusulte of the ehort term tect, the lang tera tewting w111 be done on a full alse $10 \mathrm{C20}$ megnet.

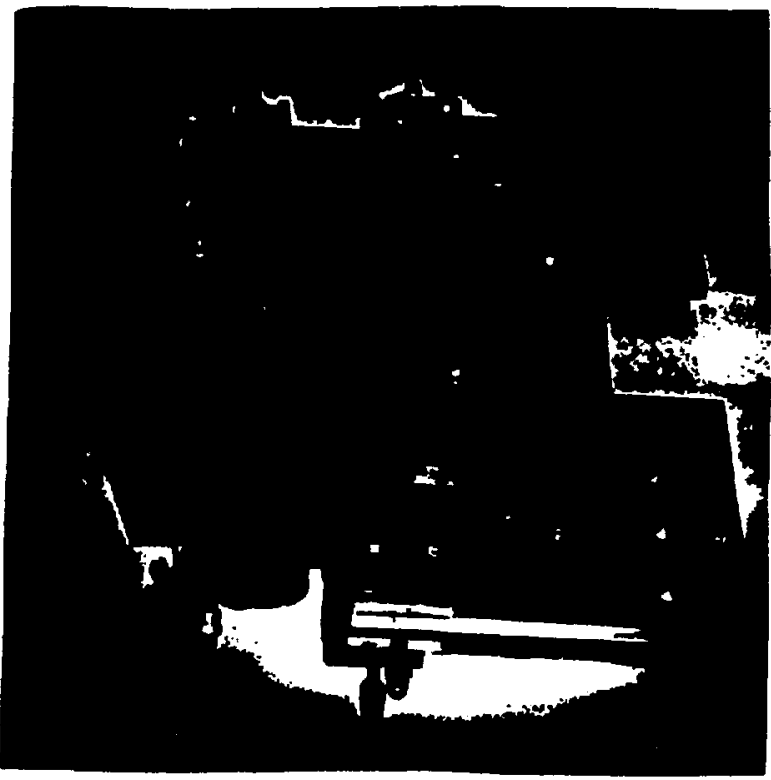

Fig. 4 Cotle in ted magnet.

\section{Acknowledracente}

The author withas to acknowledge the valueble contributions of the following people:

Mr. Merrill Roberte of Enerson Electrlc Co., RA for several helpful diecuselone.

Mr. Ton Sariaky of Precialon Tube Co., Inc., North Weles, $\mathrm{PA}$ for accompliahing the fabrication of the Alclad conductor.

Mr. Frank Kraft of Anecote Corp., Long Ioland Clty, NY for providing the anodizing for the colla.

The AGS'• Experiaentel Areee Group tor winding the colla, asaembling, and teating the magnet.

\section{References}

(1) Beavia, D., et al, "H1gh Intenu1ty Target Station": Pheso I, Private Comunication, , Nov. 1988.

(2) Catalog, Pyrotenax of Canada Led, Tranton, Oncerto, Cansda.

[3] Holland, M.M. and Joseph Sh111, "Red1at1on Resietant Magnet Cotlo tran hard Anodized Aluininum Condictor," Llate Trana Nuc $8 \mathrm{cl}$, vol NS-20, No. 3, June 73, pp. 708-712. 


\section{DISCLAIMER}

This report was prepared as an account of work sponsored by an agency of the United States Government. Neither the United States Government nor any agency thereof, nor any of their employees, makes any warranty, express or implied, or assumes any legal liability or responsibility for the accuracy, completeness, or usefulness of any information, apparatus, product, or process disclosed, or represents that its use would not infringe privately owned rights. Reference herein to any specific commercial product, process, or service by trade name, trademark, manufacturer, or otherwise does not necessarily constitute or imply its endorsement, recommendation, or favoring by the United States Government or any agency thereof. The views and opinions of authors expressed herein do not necessarily state or reflect those of the United States Government or any agency thereof. 